$\begin{array}{ll}\text { Research Square } & \begin{array}{l}\text { Preprints are preliminary reports that have not undergone peer review. } \\ \text { They should not be considered conclusive, used to inform clinical practice, } \\ \text { or referenced by the media as validated information. }\end{array}\end{array}$

\title{
Impact of Angiotensin-converting Enzyme Inhibitors and Angiotensin Receptor Blockers on Inflammatory Responses and Viral Clearance in COVID- 19 Patients: A Multicenter Retrospective Cohort Study
}

\section{Linna HUANG}

Center for Respiratory Diseases, China-Japan Friendship Hospital; Department of Pulmonary and Critical Care Medicine, China-Japan Friendship Hospital; National Clinical Research Center for Respiratory Diseases, Beijing, China

\section{Ziying CHEN}

Peking University Health Science Center

Lan NI

Department of Pulmonary and Critical Care Medicine, Zhongnan Hospital of Wuhan University, Wuhan, Hubei, China

\section{Lei CHEN}

Department of Pulmonary and Critical Care Medicine, Tongji Hospital, Tongji Medical College, Huazhong University of Science and Technology, Wuhan,

Hubei, China

Changzhi ZHOU

Department of Pulmonary and Critical Care Medicine, The Central Hospital of Wuhan, Wuhan, Hubei, China

Chang GAO

Department of Critical Care Medicine, The First Affiliated Hospital of Soochow University, Suzhou, Jiangsu, China

Xiaojing WU

Center for Respiratory Diseases, China-Japan Friendship Hospital; Department of Pulmonary and Critical Care Medicine, China-Japan Friendship Hospital; National Clinical Research Center for Respiratory Diseases, Beijing, China

Lin HUA

School of Biomedical Engineering, Capital Medical University, Beijing, P. R. China

Xiaoyang CUI

Center for Respiratory Diseases, China-Japan Friendship Hospital; Department of Pulmonary and Critical Care Medicine, China-Japan Friendship Hospital; National Clinical Research Center for Respiratory Diseases, Beijing, China

Ye TIAN

Center for Respiratory Diseases, China-Japan Friendship Hospital; Department of Pulmonary and Critical Care Medicine, China-Japan Friendship Hospital; National Clinical Research Center for Respiratory Diseases, Beijing, China

Qingyuan ZHAN ( $\nabla$ drzhanqy@163.com)

Center for Respiratory Diseases, China-Japan Friendship Hospital; Department of Pulmonary and Critical Care Medicine, China-Japan Friendship Hospital; National Clinical Research Center for Respiratory Diseases, Beijing, China

\section{Research Article}

Keywords: ACE inhibitor, ARB, inflammatory response, viral clearance

Posted Date: May 8th, 2020

DOI: https://doi.org/10.21203/rs.3.rs-27366/v1

License: @) (7) This work is licensed under a Creative Commons Attribution 4.0 International License. Read Full License 


\section{Abstract}

Objectives: To evaluate the impact of angiotensin-converting enzyme inhibitors (ACEls) or angiotensin receptor blockers (ARBs) on coronavirus disease 2019 (COVID-19) patients.

Methods: We included 229 patients with confirmed COVID-19 in a multicenter, retrospective cohort study. Propensity score matching at a ratio of 1:4 was introduced to eliminate the potential confounders. Patients were assigned to the ACEI/ARB group $(n=40)$ or control group ( $n=160)$ according to whether they were current users of medication.

Results: Compared to the control group, patients in the ACEI/ARB group had lower levels of plasma IL- $1 \beta[(6.27 \pm 0.50) \mathrm{vs}$. (8.23 \pm 0.39$) \mathrm{pg} / \mathrm{ml}, P=0.028]$, IL-8 [(35.74 \pm 4.00$)$ vs. $(45.88 \pm 2.06) \mathrm{pg} / \mathrm{ml}, P=0.037]$ and TNF-a $[(8.79 \pm 0.40)$ vs. $(10.91 \pm 0.21) \mathrm{pg} / \mathrm{ml}, P<0.01]$. Patients with the current use of ACEls/ARBs had a higher risk of shock $(23 \%$ vs. $8 \%, P<0.01)$. Decreased lymphocyte counts $\left[(0.85 \pm 0.45)\right.$ vs. $\left.(1.02 \pm 0.52) * 10^{\wedge} 9 / \mathrm{L}, \mathrm{P}=0.041\right]$ and elevated plasma levels of IL-10 $[(7.39 \pm 0.51)$ vs. $(6.18 \pm 0.16) \mathrm{pg} / \mathrm{ml}, P<0.01]$ were also important discoveries in the ACEl/ARB group. Patients in the ACEl/ARB group had a prolonged duration of viral shedding $[(25 \pm 7)$ vs. $(20 \pm 6)$ days, $P=0.031]$ and increased length of hospitalization $[(23 \pm 12)$ vs. $(16 \pm 8)$ days, $P<0.01]$. These trends were similar in patients with hypertension.

Conclusions: For patients with excessive inflammatory responses and stable hemodynamics, ACEls or ARBs might be tried to relieve the inflammatory storm, but the antiviral treatment should be enforced and the hemodynamics should be monitored closely; for patients with low levels of proinflammatory factors or instability hemodynamics, the agents might not be used to avoid a delay in viral clearance or increase the risk of shock.

\section{Introduction}

Up to March 31, 2020, the total number of patients with coronavirus disease 2019 has risen sharply to nearly 700,000 globally, with a mortality of nearly $5 \%$. Meanwhile, this epidemic seems to be spreading at an exponential rate and has become an urgent public health emergency of international concern.

Several large retrospective studies have revealed that pre-existing cardiovascular disease and diabetes were the most frequent comorbidities of coronavirus disease 2019 (COVID-19) patients ${ }^{[1-3]}$; these patients even had a higher risk of mortality ${ }^{[4,5]}$ than those with underlying respiratory disease. Angiotensinconverting enzyme inhibitors (ACEIs) and angiotensin receptor blockers (ARBs) are widely prescribed for these patients. ACEls/ARBs have an impact on the renin-angiotensin system (RAS) and are postulated to attenuate pulmonary and systemic inflammatory responses, reducing the severity and mortality of viralpneumonia-related acute respiratory distress syndrome ${ }^{[6-8]}$, ultimately by angiotensin-converting enzyme 2 (ACE2) upregulation through the ACE2-Ang- (1-7)Mas axis ${ }^{[9]}$.

As the molecular biology of severe acute respiratory syndrome coronavirus 2 (SARS-CoV-2) is well established, it appears to bind to its target cells through ACE2, which is expressed by epithelial cells of the lung to enable it to infect host cells ${ }^{[10,11]}$. The expression of ACE2 is substantially increased in patients who are treated with ACE inhibitors and ARBs ${ }^{[12]}$, which promotes SARS-CoV-2 entry into the body, increasing the risk of developing COVID-19 ${ }^{[13,14]}$.

The controversial pathogenesis as well as the mixed results of several clinical studies ${ }^{[15,16]}$ of pneumonia with other pathogens made it difficult for physicians to determine whether the use of ACE inhibitors or ARBs should be terminated in patients with COVID-19.

To date, the actual impact of ACE inhibitor and ARB prescriptions on COVID-19 patients has not been assessed in current studies. Therefore, we aimed to evaluate the clinical manifestations, inflammatory responses, viral clearance and outcomes by a multicenter, retrospective cohort study.

\section{Materials And Methods}

\section{Study design and population}

We retrospectively included patients with confirmed cases of COVID-19 according to the World Health Organization (WHO) $)^{[17]}$ and Chinese official guidelines ${ }^{[18]}$ in a multicenter retrospective cohort study performed at three tertiary hospitals in Wuhan, Hubei Province, China (Tongji Hospital, Tongji Medical College, Huazhong University of Science and Technology; Zhongnan Hospital of Wuhan University; and the Central Hospital of Wuhan) from February 15, 2020 to March 25, 2020.

\section{Exclusion criteria}

1) Patients younger than 18 years old.

2) Noncurrent users of ACE inhibitors or ARBs prior to hospitalization.

3) Patients still hospitalized at the end of the study.

All patients were treated according to the standard protocols for antiviral, antibiotic, glucocorticoid, and Chinese medicine treatments.

The ethics committee of China-Japan Friendship Hospital approved this study (2020-21-K16). Written informed consent was waived due to the rapid emergence of this infectious disease. Written informed consent was waived due to the rapid emergence of this infectious disease.

\section{Group division}


We divided the patients into two groups. The ACEI/ARB group included patients who were current users of ACE inhibitor or ARB medication, while the control group included noncurrent users. Patients in the ACEI/ARB group were further divided into subgroups of a continued medication group and a terminated medication group according to the application of ACE inhibitors or ARBs during hospitalization.

\section{Data collection and analysis}

We collected data on the following parameters from the hospital electronic medical record systems, nursing records, laboratory examination systems, and radiological examinations and obtained standardized data collection forms: demographic characteristics, comorbidities, medication history within one month, symptoms at admission, laboratory finding changes from day 1 to day 14, radiological manifestations, treatment during hospitalization and outcome data that contained the rate of in-hospital death and progression, the duration of viral shedding, the length of hospital stay and the time from onset to death or discharge. Patients with cardiovascular disease and diabetes often combined the medication with statins ${ }^{[19]}$ and oral hypoglycemic agents, especially thiazolidinediones, which have been reported to have an impact on the level of ACE2 by several studies ${ }^{[14,20]}$. To further control for potential confounders, data on the use of statins, thiazolidinediones and other antihypertensive agents ( $\beta$ receptor blocking agent and diuretics) prior to admission in each group were calculated within 90 days ${ }^{[6]}$.

Two researchers also independently reviewed the data collection forms to double check the data collected. Any missing or uncertain records of the epidemiological, medication and symptom data were collected and clarified through direct communication with patients and their families.

We compared the two groups in terms of the above aspects to identify the differences between ACE inhibitor or ARB users with nonusers prior to admission. Then, a subgroup analysis was conducted by comparing the dynamic changes of indicators involved in immune status and inflammatory reactions, as well as the outcomes between patients who continued and terminated medication during hospitalization. As hypertension itself could activate the RAS, patients with hypertension were excluded to avoid potential confounders. A comparison of the immune status, inflammatory reactions and outcomes between the ACEI/ARB and control groups in patients without hypertension was conducted.

\section{Cytokine and chemokine measurement}

To evaluate the impact of coronavirus and additional ACE inhibitors or ARBs on the production of cytokines or chemokines in the acute phase of the illness, plasma cytokines and chemokines [interleukin $1 \beta$ (IL-1 $\beta$ ), IL-2R, IL-6, IL-8, IL-10 and tumor necrosis factor a (TNF- $\alpha$ )] were measured using chemiluminescent immunoassay (CLIA) (CFDA approved) by Siemens IMMULITE 1000 for patients according to the manufacturer's instructions.

\section{Definitions}

Medications classified as ACE inhibitors were benazepril, perindopril and fosinopril, while the ARBs of the included patients were candesartan, irbesartan, valsartan, olmesartan, telmisartan and losartan. The effective half-life period of the above agents varied from 6 to 50 hours; therefore, it took no more 10 days to achieve a stable blood drug concentration.

Patients were considered a current user of medication if they had a supply of medication to last until the date of hospitalization assuming an $80 \%$ compliance rate $^{[6,21]}$. The patients who did not meet the definition were regarded as noncurrent users. ACE inhibitors or ARBs were considered to be continued if they were given more than $50 \%$ of the days during hospitalization ${ }^{[8]}$; otherwise, they were considered to be terminated.

In-hospital progression was defined as a decline in $\mathrm{PaO}_{2} / \mathrm{FiO}_{2}$ of more than $100 \mathrm{mmHg}$ or the need for invasive positive pressure ventilation (IPPV) and/or extracorporeal membrane oxygenation (ECMO) during hospitalization.

Shock was defined according to the interim guidance of the WHO for novel coronavirus ${ }^{[22,23]}$. Acute kidney injury (AKI) was identified and classified on the

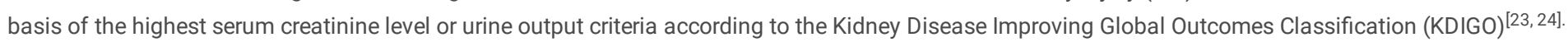
Respiratory failure, coagulation and liver failure were defined as a Sequential Organ Failure Assessment (SOFA) score greater than or equal to two points.

\section{Statistical analysis}

Descriptive statistics included proportions for categorical variables and the mean (standard deviation) or median (interquartile range) for continuous variables. Data were unadjusted unless specifically stated otherwise.

\section{Processing of missing data}

When the missing rate of vital variables involved in our study was less than $15 \%$, we used SAS predictive mean matching imputation to replace missing values within each variable, while the variables were abandoned when the missing rate reached $20 \%$.

\section{Processing of the unbalanced sample size: propensity score matching}

The propensity score matching (PSM) method was applied at a ratio of 1:4 between the ACEI/ARB group and the control group. Age, sex and medication history prior admission which might be potential confounders associated with ACEl/ARB were matched variables in PSM to derive the cohort.

Proportions were compared using $\chi 2$ or Fisher's exact tests, and continuous variables were compared using the $t$ test or Wilcoxon rank sum test, as appropriate. Statistical significance was defined as a 2-tailed $P$ value of $\leq .05$. SAS software, version 9.4 (SAS Institute Inc.) was used for all analyses. 


\section{Results}

From February 15, 2020 to March 25, 2020, a total of 229 patients with confirmed cases of COVID-19 were admitted, and 175 patients not taking an ACE inhibitor or ARB medication. Among the 54 patients with a medication history, three of them were regarded as noncurrent users according to the definition and were excluded ultimately. The propensity score matching (PSM) method was applied at a ratio of 1:4 between the ACEl/ARB group ( $n=40$ ) and the control group $(n=160)$. Age, sex and medication history 90 days prior admission were matched variables in PSM to derive the cohort. Among the patients with the ACEI/ARB medication, 17 continued medication during hospitalization, while the other 34 terminated medication (Figure 1). The mean age was $58 \pm 17$ years, male patients accounted for $58 \%(n=115)$, and the disease severity status ${ }^{[18]}$ at admission was general for most of the study cohort $(n=144,72 \%)$.

\section{Comparisons of baseline prior hospitalization between the ACEI/ARB and control groups (Table 1)}

The ACEI/ARB group included more patients with hypertension ( $75 \%$ vs. $23 \%, P<0.01)$ than the control group. The demographic characteristics, other comorbidities, severity of the condition and possible medication histories might have influenced the ACE2 level but did not differ significantly between the two groups. No significant difference was found between the two groups in time from onset to hospitalization and to COVID-19 diagnosis.

\section{Comparisons of clinical symptoms, laboratory examinations and radiological manifestations on admission between the ACEI/ARB and control groups (Table 2)}

The symptoms, including fever, cough, hemoptysis, dyspnea, fatigue/myalgia and diarrhea, as well as vital signs, were not significantly different between the ACEI/ARB group and the control group. For laboratory examinations, patients with ACE inhibitor or ARB medication had lower lymphocyte counts $[(0.85 \pm 0.45)$ vs. $\left.(1.02 \pm 0.52) * 10^{\wedge} 9 / \mathrm{L}, \mathrm{P}=0.041\right]$ and higher levels of lactate dehydrogenase $(\mathrm{LDH})[(377 \pm 130) \mathrm{vs}$. $(289 \pm 158) \mathrm{IU} / \mathrm{L}, P<0.001]$ and $\mathrm{D}$-dimer $[(3.33 \pm 0.89)$ vs. $(1.65 \pm 0.25) \mu \mathrm{g} / \mathrm{ml}, P=0.015]$ than the control group.

The inflammatory factors, including IL-1 $\beta, \mathrm{IL}-2 \mathrm{R}, \mathrm{IL}-6, \mathrm{IL}-8, \mathrm{IL}-10$ and TNFa, were chosen from the first value within three days of admission, and as the missing rate reached $12-15 \%$, the SAS predictive mean matching imputation was applied to replace missing values of each group. The missing rate of IL-2R, serum ferritin, erythrocyte sedimentation rate (ESR) and C-reactive protein (CRP) were as high as 25-35\%; therefore, they were abandoned in statistical analysis. Patients in the ACEI/ARB group had slightly lower levels of proinflammatory cytokines, including IL- $1 \beta[(6.27 \pm 0.50) \mathrm{vs}$. (8.23 \pm 0.39$) \mathrm{pg} / \mathrm{ml}, P=0.028]$, IL-8 $[(35.74 \pm 4.00)$ vs. $(45.88 \pm 2.06) \mathrm{pg} / \mathrm{ml}, P=0.037]$ and TNF-a [(8.79 \pm 0.40$)$ vs. $(10.91 \pm 0.21) \mathrm{pg} / \mathrm{ml}, P<0.01]$, and higher levels of anti-inflammatory cytokines [IL10: $(10.39 \pm 0.51)$ vs. $(6.18 \pm 0.16) \mathrm{pg} / \mathrm{ml}, P<0.01]$ than the control group.

\section{Comparison of organ function, treatment and outcomes during hospitalization between the ACEI/ARB and control groups (Table 3)}

Patients with current use of ACE inhibitors or ARBs seemed to have a higher risk of developing shock $(23 \%$ vs. $8 \%, P<0.01)$ and the application of vasoconstrictive agents $(20 \%$ vs. $6 \%, P<0.01)$ than the control group; however, the percentages of respiratory failure, AKI, coagulation failure and liver failure were not different from those of the control group. In addition, the necessities for invasive IPPV and ECMO were not decreased in the ACEI/ARB group.

The duration of viral shedding [(25 \pm 7$)$ vs. $(20 \pm 6)$ days, $P=0.031]$, length of hospital stay [(23 \pm 12$)$ vs. $(16 \pm 8)$ days, $P<0.01]$ and time from onset to death or discharge $[(33 \pm 14)$ vs. $(27 \pm 10)$ days, $P<0.01]$ were longer in the ACEI/ARB group than in the control group, while no difference was found in the rate of inhospital progression or death.

\section{Subgroup analyses: comparison between patients who continued and terminated medication during hospitalization}

Among the patients with ACEI/ARB medication, 17 continued medication during hospitalization, while the other 34 terminated medication for several reasons. The dynamic changes in indicators involved in immune status and inflammatory reactions at the first, seventh, and fourteenth days of hospitalization as well

as the outcomes were compared between the two groups. The missing rates of IL-2R and IL-8 at seven days and fourteen days after admission were extremely high and were not included in the analysis. Patients with continued use of ACE inhibitor or ARB had a consistently lower level of IL-1 $\beta$ and TNF- $\alpha$ at seventh day; while maintained higher level of the IL-10 from the seventh day to the fourteenth day than patients terminated the medication. However, the patients who terminated the medication had a trend of elevated lymphocyte counts [day 1 , day 7 , day $14:(1.09 \pm 0.52)$ vs. $(1.30 \pm 0.86)$ vs. $(1.60 \pm 0.52)^{\star} 10^{\wedge} 9 / \mathrm{L}, P<0.01$ ] from the first day to the fourteenth day, had a trend of higher levels of IL-1 3 [day 1 , day 7 , day $14:(6.03 \pm 3.19) \mathrm{vs}$. (10.78 \pm 6.88$) \mathrm{vs}$. (6.52 \pm 3.33$) \mathrm{pg} / \mathrm{ml}, P<0.01] \mathrm{and}$ TNF-a [day 1, day 7, day 14: $(9.19 \pm 2.86)$ vs. $(18.39 \pm 8.47)$ vs. $(6.15 \pm 2.15) \mathrm{pg} / \mathrm{ml}, P<0.01]$ at the seventh day, which returned to the baseline level on the fourteenth day (Table 4, Figure 2).

The duration of viral shedding [(27 \pm 7$)$ vs. $(21 \pm 7)$ days, $P=0.042]$, length of hospital stay $[(27 \pm 9)$ vs. $(21 \pm 11)$ days, $P=0.037]$ and time from onset to death or discharge $[(33 \pm 13)$ vs. $(29 \pm 14)$ days, $P=0.038]$ were longer in the continued medication group than in the terminated medication group. The rate of in-hospital progression and death were not significantly different between the two groups (Table 5).

\section{Subgroup analyses: a comparison of the immune status, inflammatory reactions and outcomes between the ACEl/ARB and control groups in patients with hypertension}

Among 66 patients with hypertension, 30 patients were divided into the study group (ACEls/ARBs group) and the other 36 patients were in the control group.

Compared with the control group, the patients in the study group had lower levels of IL-1 $\beta[(6.41 \pm 0.34) \mathrm{vs}$. (8.36 \pm 0.21$) \mathrm{pg} / \mathrm{ml}, P=0.039]$ and IL-8 [(33.2 \pm 3.64$)$ vs. $(42.39 \pm 1.21) \mathrm{pg} / \mathrm{ml}, P=0.027]$ on admission. Regarding clinical outcomes, the duration of viral shedding [(26 \pm 9$)$ vs. (19 \pm 7$)$ days, $P=0.024]$ and time from onset to death or discharge [( $31 \pm 11)$ vs. $(25 \pm 9)$ days, $P=0.032]$ was longer in the study group than in the control group; however, no difference was detected in the rate of in-hospital progression and death between the two groups. 


\section{Discussion}

To our knowledge, this is the first study to evaluate the clinical manifestations, inflammatory responses, and viral clearence of COVID-19 patients treated with ACE inhibitor and ARB medication by a multicenter, retrospective cohort control study and to allow a dynamic observation of inflammatory responses by continuous monitoring from the first to fourteenth day.

The major findings of our study were that ACE inhibitor or ARB medication had an impact on inhibiting the proinflammatory response but promoted the antiinflammatory response persistently and extended the duration of viral shedding, had an impact on hemodynamics as well. The inflammatory factors of COVID-19 patients should be monitored as route examination. For patients with excessive inflammatory responses and stable hemodynamics, ACEls or ARBs might be tried to relieve the inflammatory storm, but the antiviral treatment should be enforced and the hemodynamics should be monitored closely; for patients with low levels of proinflammatory factors or instability hemodynamics, the agents might not be used to avoid a delay in viral clearance or increase the risk of shock.

Inflammation is mediated by proinflammatory cytokines and anti-inflammatory cytokines. Inappropriate elevated expression of proinflammatory cytokines can result in sepsis, tissue destruction, or death ${ }^{[21,25]}$. Our study revealed that the plasma levels of IL-1 $\beta$, IL-8 and TNF-a in patients taking ACE inhibitor or ARB were lower than those in patients not taking medication; in addition, persistently lower levels of proinflammatory factors were maintained in patients who continued medication during hospitalization, which was consistent with the previous experimental results by Gullestad $L$ and his colleagues ${ }^{[26]}$ with the conclusion that high-dose enalapril was associated with a significant decrease in IL-6 activity in patients with severe chronic heart failure. The specific organ and systemic inflammatory responses were postulated to attenuate through a reduction in the level of cytokines, which might be explained by the attenuating effects of ACE inhibitors through the deactivation of the ACE-Angll-AT1 axis but the stimulation of the ACE2-Ang- (1-7)-Mas axis in a feedback mechanism ${ }^{[9,27,}$ ${ }^{28]}$ as a negative regulator with attenuated cytokines and thus protecting the patients from organ injury. Consequently, some authors ${ }^{[29,30]}$ have speculated that the use of ACEIs/ARBs might actually be a potentially beneficial intervention in those with COVID-19.

Apart from organ protection by attenuating the inflammatory response, basic investigation has shown that bradykinin and substance P produced by ACE inhibitors sensitize the sensory nerves of the airways and enhance the cough reflex ${ }^{[31,32]}$, which plays a protective role against pathogens. These two mechanics made it possible to improve the outcome in patients with pneumonia. Mortensen et $a^{[6]}$ found a significant decrease in mortality, the length of hospital stay, and mechanical ventilation in patients taking ACE inhibitors or ARBs who were hospitalized with pneumonia compared to a matched cohort. A meta-analysis ${ }^{[33]}$ that included 19 studies noted that patients taking ACE inhibitors were associated with a significant approximately one-third reduction in the risk of pneumonia compared with controls. In addition, a recent study ${ }^{[8]}$ by Christopher Henry also observed lower rates of death and intubation with continued use of $A C E$ inhibitors than with terminated use $(O R=0.25 ; 95 \% \mathrm{Cl}, 0.09-0.64)$ throughout the hospital stay in cases of viral pneumonia not due to coronavirus. Unfortunately, our study did not find decreased mortality in patients with current use of ACE inhibitors or ARBs, even though we analyzed patients with continued medication during hospitalization and without hypertension to avoid potential confounding factors. The most likely explanation was that our study included a small number of patients, while most of their patients had mild cases as determined by diseases severity status and without excessive inflammatory reactions, which was the target for ACE inhibitors or ARBs.

What is noteworthy is that ACE inhibitors or ARBs increased the risk of shock and the necessity of vasoconstrictive agents. It could be explained by the nature of the antihypertensive agents and came as a revelation to us that it should be avoided in patients with instability hemodynamics.

Our research also revealed that ACE inhibitors or ARBs led to prolonged viral shedding and extended the length of hospitalization. SARS-CoV-2 appears to bind to its target cells through angiotensin-converting enzyme 2 (ACE2). ACE inhibitors or ARBs upregulate ACE2 receptor expression in humans ${ }^{[34]}$ by blocking the classic ACE pathway; thus, it is theoretically possible that the pre-existing use of these drugs might predispose a person to infection with a greater viral load of

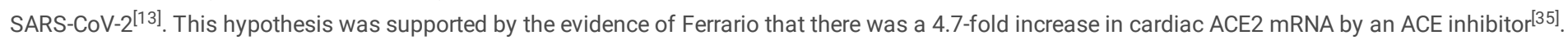
Decreased lymphocyte counts and elevated plasma levels of IL-10 were also important discoveries in patients with ACE inhibitors or ARBs. Moreover, the lymphocyte counts in patients with continued use of an ACE inhibitor or ARB during hospitalization recovered slowly, as observed by successive monitoring on the first to fourteenth days. The immune status was weakened by lymphocytopenia and elevated anti-inflammatory cytokines in patients taking ACEls, which might be another reason for the slow viral clearance. As the important criterion for discharge was the negative conversion of the SARS-CoV-2, prolonged viral shedding led to an extended length of hospitalization. This might be the defect of the ACE inhibitor or ARB and could explain the mixed results and controversy about their prescription in COVID-19 patients. For this reason, antiviral therapy in patients taking ACE inhibitors or ARBs for the purpose of relieving the inflammatory response should be reinforced, and their viral load should be monitored closely; however, in patients with low levels of proinflammatory factors, ACE inhibitors or ARBs should be not be used to avoid a delay in viral clearance.

An autopsy report revealed that mononuclear inflammatory infiltration dominated by lymphocytes was observed in the lungs, but no virus inclusion bodies were found ${ }^{[36]}$. We could then propose a hypothesis that cytokines released by inflammatory storms secondary to viral infection might be more important in the death of critically ill patients with COVID-19 than the viral infection itself in a certain period. From this perspective, it is possible that ACE inhibitors or ARBs might improve the outcome in critically ill patients with excessive inflammatory responses or severe multiple organ failure; when the inflammatory storm gradually diminishes, the focus of therapy should be on clearance of the virus and the enhancement of the immune system; and ACE inhibitors or ARBs with the adverse effect of prolonged viral shedding and weakening the defense of the immune system to some degree should be terminated. Prospective cohort and randomized controlled trials are needed to confirm this hypothesis and examine potential mechanisms of action.

Our study was limited by the small number of patients included and by not strictly excluding confounding factors, such as other medications, diabetes, coronary heart disease and chronic heart failure that might influence the RAS ${ }^{[37]}$. However, the PSM method was applied to eliminate bias. We also noticed that the number of patients with hypertension was much higher in the ACEI/ARB group, which might be an important confounding factor. By subgroup 
analyze, we found a similar result. We encourage further prospective randomized controlled studies designed by increasing the sample size and strictly excluding potential confounders to explore the impact of ACE inhibitors or ARBs on inflammatory responses, viral clearance and mortality in COVID-19 patients.

\section{Declarations}

\section{Consent for publication}

Not applicable.

\section{Ethics approval and consent to participate}

The ethics committee of China-Japan Friendship Hospital approved this study (2020-21-K16). Written informed consent was waived due to the rapid emergence of this infectious disease.

\section{Availability of data and materials}

The datasets used and/or analysed during the current study are available from the corresponding author upon reasonable request.

\section{Competing Interests}

The authors declare that they have no competing interests.

\section{Funding}

The study was supported by the grants from the Zhejiang University special scientific research fund for COVID-19 prevention and control (2020XGZX008). The funder had no role in study design, data collection and analysis, decision to publish, or preparation of the manuscript.

\section{Authors' contributions}

All authors made substantial contributions to the conception and design of the study or to the data acquisition, analysis or interpretation; reviewed and approved the final manuscript; and significantly contributed to this study. Dr. Zhan took full responsibility for the integrity of the submission and publication and was involved in the study design. Drs. Linna Huang and Ziying Chen involved in data collection, had full access to all of the data in the study, took responsibility for the integrity of the data and were responsible for data verification, as well as the drafting of the manuscript. Pro. Lin Hua took the responsibility for statistical analysis and the accuracy of the data analysis. Others involved in in data collection, had full access to all of the data in the study, and took responsibility for the integrity of the data.

\section{Acknowledgements}

Not applicable.

\section{References}

[1]. Yang X, Yu Y, Xu J, Shu H, Xia J, Liu H, et al. Clinical course and outcomes of critically ill patients with SARS-CoV-2 pneumonia in Wuhan, China: a singlecentered, retrospective, observational study. Lancet Respir Med 2020; 8(4):e26.

[2]. Guan WJ, Ni ZY, Hu Y, Liang WH, Ou CQ, He JX, et al. Clinical Characteristics of Coronavirus Disease 2019 in China. N Engl J Med 2020 Feb 28 [Online ahead of print].

[3]. Zhang JJ, Dong X, Cao YY, Yuan YD, Yang YB, Yan YQ, et al. Clinical characteristics of 140 patients infected with SARS-CoV-2 in Wuhan, China. Allergy 2020 Feb 19 [Online ahead of print].

[4]. Wu C, Chen X, Cai Y, Xia J, Zhou X, Xu S, et al. Risk Factors Associated With Acute Respiratory Distress Syndrome and Death in Patients With Coronavirus Disease 2019 Pneumonia in Wuhan, China. JAMA Intern Med 2020 Mar 13 [Online ahead of print].

[5]. Zhou F, Yu T, Du R, Fan G, Liu Y, Liu Z, et al. Clinical course and risk factors for mortality of adult inpatients with COVID-19 in Wuhan, China: a retrospective cohort study. Lancet 2020, 395(10229):1054-1062.

[6]. Mortensen EM, Pugh MJ, Copeland LA, Restrepo MI, Cornell JE, Anzueto A, et al. Impact of statins and angiotensin-converting enzyme inhibitors on mortality of subjects hospitalised with pneumonia. The Eur Respir J 2008, 31(3):611-617.

[7]. Wu A, Good C, Downs JR, Fine MJ, Pugh MJ, Anzueto A, et al. The association of cardioprotective medications with pneumonia-related outcomes. PloS one 2014, 9(1):e85797.

[8]. Henry C, Zaizafoun M, Stock E, Ghamande S, Arroliga AC, White HD. Impact of angiotensin-converting enzyme inhibitors and statins on viral pneumonia. Proceedings 2018, 31(4):419-423. 
[9]. Tan WSD, Liao W, Zhou S, Mei D, Wong WF: Targeting the renin-angiotensin system as novel therapeutic strategy for pulmonary diseases. Curr Opin Pharmacol 2018, 40:9-17.

[10]. Walls AC, Park YJ, Tortorici MA, Wall A, McGuire AT, Veesler D. Structure, Function, and Antigenicity of the SARS-CoV-2 Spike Glycoprotein. Cell 2020 Mar $6[$ Online ahead of print].

[11]. Hoffmann M, Kleine-Weber H, Schroeder S, Kruger N, Herrler T, Erichsen S, et al. SARS-CoV-2 Cell Entry Depends on ACE2 and TMPRSS2 and Is Blocked by a Clinically Proven Protease Inhibitor. Cell 2020 Mar 4[Online ahead of print].

[12]. Li XC, Zhang J, Zhuo JL. The vasoprotective axes of the renin-angiotensin system: Physiological relevance and therapeutic implications in cardiovascular, hypertensive and kidney diseases. Pharmacological Res 2017, 125(Pt A):21-38.

[13]. Thomson G. COVID-19: social distancing, ACE 2 receptors, protease inhibitors and beyond? Int J Clin Pract 2020:e13503.

[14]. Fang L, Karakiulakis G, Roth M. Are patients with hypertension and diabetes mellitus at increased risk for COVID-19 infection? The Lancet Respir Med 2020. 8 (4):e21.

[15]. Okaishi K, Morimoto S, Fukuo K, Niinobu T, Hata S, Onishi T, et al. Reduction of risk of pneumonia associated with use of angiotensin I converting enzyme inhibitors in elderly inpatients. Am J Hypertens 1999, 12 (8 Pt 1):778-783.

[16]. Van de Garde EM, Souverein PC, van den Bosch JM, Deneer VH, Leufkens HG. Angiotensin-converting enzyme inhibitor use and pneumonia risk in a general population. Eur Respir J 2006, 27(6):1217-1222.

[17]. Organization WH (2020) Clinical management of severe acute respiratory infection when Novel coronavirus (nCoV) infection is suspected: Interim Guidance. https://www.who.int/publications-detail/clinical-management-of-severe-acute-respiratory-infection-when-novel- coronavirus-(ncov)-infection-issuspected.

[18]. National Health Commission of the People's Republic of China. $\otimes$ Chinese management guideline for COVID-19 (version 7.0). March 4, 2020.http://211.136.65.146/cache/www.nhc.gov.cn/yzygj/s7653p/202003/46c9294a7dfe4cef80dc7f5912eb1989/files/ce3e6945832a438eaae415350a8ces ich_args $2=65-$

11155015043898_f32a0b9f969d8670abb9ee3d42d8e898_10001002_9c896c2ad2caf0d59239518939a83798_0ad7c3e0d3161a7f69a04f61b3ce861b.

[19]. Chopra V, Rogers MA, Buist M, Govindan S, Lindenauer PK, Saint S, et al. Is statin use associated with reduced mortality after pneumonia? A systematic review and meta-analysis. Am J Med. 2012, 125(11):1111-1123.

[20]. Wan Y, Shang J, Graham R, Baric RS, Li F. Receptor Recognition by the Novel Coronavirus from Wuhan: an Analysis Based on Decade-Long Structural Studies of SARS Coronavirus. J Virol 2020, 94(7).

[21]. Mortensen EM, Nakashima B, Cornell J, Copeland LA, Pugh MJ, Anzueto A, et al. Population-based study of statins, angiotensin II receptor blockers, and angiotensin-converting enzyme inhibitors on pneumonia-related outcomes. Clin Infect Dis 2012, 55(11):1466-1473.

[22]. WHO. Summary of probable SARS cases with onset of illness from 1 November 2002 to 31 July 2003. Dec 31, 2003. https://www. who.int/csr/sars/country/table2004_04_21/en/ (accessed囚Jan 19, 2020). 『

[23]. Huang C, Wang Y, Li X, Ren L, Zhao J, Hu Y, et al. Clinical features of patients infected with 2019 novel coronavirus in Wuhan, China. Lancet 2020, 395(10223):497-506.

[24]. Kidney disease: improving global outcomes (KDIGO) acute kidney injury work group. KDIGO clinical practice guideline for acute kidney injury. March, 2012. https://kdigo.org/wp-content/uploads/2016/10/KDIGO-2012-AKI-Guideline-English.pdf (accessed Jan 23, 2020).

[25]. Nathan C. Points of control in inflammation. Nature 2002, 420(6917):846-852.

[26]. Gullestad L, Aukrust P, Ueland T, Espevik T, Yee G, Vagelos R, et al. Effect of high- versus low-dose angiotensin converting enzyme inhibition on cytokine levels in chronic heart failure. J Am Coll Cardiol 1999, 34(7):2061-2067.

[27]. Duprez DA. Role of the renin-angiotensin-aldosterone system in vascular remodeling and inflammation: a clinical review. J Hypertension 2006, 24(6):983991.

[28]. Marchesi C, Paradis P, Schiffrin EL. Role of the renin-angiotensin system in vascular inflammation. Trends Pharmacol Sci 2008, 29(7):367-374.

[29]. Liu Y, Yang Y, Zhang C, Huang F, Wang F, Yuan J, et al. Clinical and biochemical indexes from 2019-nCoV infected patients linked to viral loads and lung injury. Sci China Life Sci.2020, 63(3):364-374.

[30]. Sun Meili, Yang Jianmin, Sun Yuping, et al. Inhibitors of RAS Might Be a Good Choice for the Therapy of COVID-19 Pneumonia. Chin J Tuberc Respir Dis, 2020: 43(3):219-222. 
[31]. Fox AJ, Lalloo UG, Belvisi MG, Bernareggi M, Chung KF, Barnes PJ. Bradykinin-evoked sensitization of airway sensory nerves: a mechanism for ACEinhibitor cough. Nat Med 1996, 2(7):814-817.

[32]. Tomaki M, Ichinose M, Miura M, Hirayama Y, Kageyama N, Yamauchi H, et al. Angiotensin converting enzyme (ACE) inhibitor-induced cough and substance P. Thorax 1996, 51(2):199-201.

[33]. Caldeira D, Alarcao J, Vaz-Carneiro A, Costa J. Risk of pneumonia associated with use of angiotensin converting enzyme inhibitors and angiotensin receptor blockers: systematic review and meta-analysis. BMJ (Clinical research ed) 2012, 345:e4260.

[34]. Vuille-dit-Bille RN, Camargo SM, Emmenegger L, Sasse T, Kummer E, Jando J, et al. Human intestine luminal ACE2 and amino acid transporter expression increased by ACE-inhibitors. Amino acids 2015, 47(4):693-705.

[35]. Turgeon RD, Kolber MR, Loewen P, Ellis U, McCormack JP. Higher versus lower doses of ACE inhibitors, angiotensin-2 receptor blockers and beta-blockers in heart failure with reduced ejection fraction: Systematic review and meta-analysis. PloS one 2019, 14(2):e0212907.

[36]. WANG Hui-jun, DU Si-hao, YUE Xia, et al. Review and Prospect of Pathological Features of Corona Virus Disease. J Forensic Med, 2020: 36(1):1-5.

[37]. Patel AB, Verma A. COVID-19 and Angiotensin-Converting Enzyme Inhibitors and Angiotensin Receptor Blockers: What Is the Evidence? JAMA 2020. Mar $24[$ Online ahead of print].

\section{Tables}

Table 1. Baseline variables in the two groups prior to admission

\begin{tabular}{|c|c|c|c|c|}
\hline & $\begin{array}{c}\text { All } \\
(n=200)\end{array}$ & $\begin{array}{c}\text { ACEI/ARB } \\
\text { group } \\
(\mathrm{n}=40)\end{array}$ & $\begin{array}{l}\text { Control group } \\
(n=160)\end{array}$ & $P$ \\
\hline Age, years, mean \pm SDD & $58 \pm 17$ & $58 \pm 15$ & $58 \pm 17$ & 0.872 \\
\hline Gender (men), number (\%)] & $115(\%)$ & $23(58 \%)$ & $92(58 \%)$ & 1 \\
\hline \multicolumn{5}{|l|}{ Comorbidities, number (\%)] } \\
\hline Hypertension & $66(33 \%)$ & $30(75 \%)$ & $36(23 \%)$ & $<0.001^{\mathrm{b}}$ \\
\hline Diabetes & $33(17 \%)$ & $10(25 \%)$ & $23(14 \%)$ & 0.105 \\
\hline Coronary heart disease & $20(10 \%)$ & $7(18 \%)$ & $13(8 \%)$ & 0.077 \\
\hline Chronic heart failure & $5(3 \%)$ & $2(5 \%)$ & $3(2 \%)$ & 0.258 \\
\hline Underlying lung disease & $19(10 \%)$ & $6(15 \%)$ & $13(8 \%)$ & 0.185 \\
\hline Chronic kidney disease & $2(1 \%)$ & $0(0 \%)$ & $2(1 \%)$ & 0.477 \\
\hline Chronic liver dysfunction & $4(2 \%)$ & $0(0 \%)$ & $4(3 \%)$ & 0.383 \\
\hline Malignancy & $4(2 \%)$ & $0(0 \%)$ & $4(3 \%)$ & 0.383 \\
\hline History of smoking, number (\%)] & $26(13 \%)$ & $7(18 \%)$ & $19(12 \%)$ & 0.344 \\
\hline \multicolumn{5}{|c|}{ Other medication history within 90 days, number (\%)! } \\
\hline Corticosteroids & $0(0 \%)$ & $0(0 \%)$ & $0(0 \%)$ & 1 \\
\hline Immunosuppressants & $0(0 \%)$ & $0(0 \%)$ & $0(0 \%)$ & 1 \\
\hline Statins & $25(13 \%)$ & $5(13 \%)$ & $20(13 \%)$ & 1 \\
\hline Thiazolidinediones & $5(3 \%)$ & $1(3 \%)$ & $4(3 \%)$ & 1 \\
\hline$\beta$ receptor blocking agent & $25(13 \%)$ & $5(13 \%)$ & $20(13 \%)$ & 1 \\
\hline Diuretics & $20(10 \%)$ & $4(10 \%)$ & $16(10 \%)$ & 1 \\
\hline \multicolumn{5}{|l|}{ Diseases severity status ${ }^{*}$} \\
\hline General & $144(72 \%)$ & $24(60 \%)$ & $120(75 \%)$ & 0.103 \\
\hline Severe & $31(16 \%)$ & $9(23 \%)$ & $22(14 \%)$ & 0.171 \\
\hline Critical & $25(13 \%)$ & $7(18 \%)$ & $18(11 \%)$ & 0.285 \\
\hline \multicolumn{5}{|l|}{ Treatment before hospital, number (\%)! } \\
\hline Methylprednisolone & $15(8 \%)$ & $5(13 \%)$ & $10(6 \%)$ & 0.179 \\
\hline Antibiotic therapy & $109(55 \%)$ & $26(65 \%)$ & $83(52 \%)$ & 0.136 \\
\hline Antiviral therapy & $113(57 \%)$ & $23(58 \%)$ & $90(56 \%)$ & 0.887 \\
\hline $\begin{array}{l}\text { Time from onset to hospital admission, } \\
\text { days, mean } \pm \mathrm{SD}[\end{array}$ & $10 \pm 6$ & $11 \pm 6$ & $10 \pm 6$ & 0.405 \\
\hline Time from onset to diagnosis, days, mean \pm SDD & $8 \pm 6$ & $6 \pm 5$ & $8 \pm 6$ & 0.187 \\
\hline
\end{tabular}

a: $P<0.05 ;^{\text {b }}: P<0.01{ }^{*}$ defined according to the Chinese management guideline for COVID-19 (version 7.0$)^{[18] \square}$.

Table 2. Clinical, laboratory findings and radiological manifestations in the two groups on admission

\begin{tabular}{lcccc}
\hline & $\begin{array}{c}\text { All } \\
(\mathrm{n}=200)\end{array}$ & $\begin{array}{c}\text { ACEI/ARB } \\
\text { group } \\
(\mathrm{n}=40)\end{array}$ & $\begin{array}{c}\text { Control } \\
\text { group } \\
(\mathrm{n}=160)\end{array}$ & $\mathrm{P}$ \\
\hline $\begin{array}{l}\text { l symptoms, number (\%) } \\
\text { rer }\left(\geq 37.3^{\circ} \mathrm{C}\right)\end{array}$ & $188(94 \%)$ & $36(90 \%)$ & $152(95 \%)$ & 0.234 \\
\hline ugh & $141(71 \%)$ & $30(75 \%)$ & $111(69 \%)$ & 0.485 \\
\hline ductive cough & $79(40 \%)$ & $17(43 \%)$ & $62(39 \%)$ & 0.664 \\
\hline moptysis & $6(3 \%)$ & $2(5 \%)$ & $4(3 \%)$ & 0.407 \\
\hline
\end{tabular}




\begin{tabular}{|c|c|c|c|c|}
\hline spnea & бу (\%) & $\angle S(\supset 8 \%)$ & ob $(41 \%)$ & u.uo4 \\
\hline igue or myalgia & $94(47 \%)$ & $18(45 \%)$ & $76(48 \%)$ & 0.777 \\
\hline irrhea & $51(26 \%)$ & $13(33 \%)$ & $38(24 \%)$ & 0.256 \\
\hline \multicolumn{5}{|l|}{1 signs, mean $\pm S D$} \\
\hline yhest temperature, ${ }^{\circ} \mathrm{C}$ & $38.5 \pm 0.7$ & $38.6 \pm 0.7$ & $38.5 \pm 0.6$ & 0.207 \\
\hline spiratory rate, breaths/min & $23 \pm 5$ & $24 \pm 6$ & $23 \pm 5$ & 0.179 \\
\hline art rate, beats/min & $96 \pm 13$ & $99 \pm 13$ & $95 \pm 13$ & 0.059 \\
\hline stolic blood pressure, $\mathrm{mmHg}$ & $124 \pm 18$ & $118 \pm 17$ & $126 \pm 20$ & $0.033^{\mathrm{a}}$ \\
\hline $\mathrm{J}_{2}, \%$ & $94 \pm 7$ & $93 \pm 6$ & $94 \pm 7$ & 0.451 \\
\hline$)_{2}, \%$ & $42 \pm 18$ & $43 \pm 17$ & $41 \pm 18$ & 0.511 \\
\hline \multicolumn{5}{|l|}{ ratory examination, mean $\pm \mathrm{SD}$} \\
\hline \multicolumn{5}{|l|}{ I routine } \\
\hline iC, $* 10^{\wedge} 9 / \mathrm{L}$ & $6.16 \pm 3.80$ & $7.01 \pm 3.96$ & $5.98 \pm 3.75$ & 0.084 \\
\hline utrophil count, $* 10^{\wedge} 9 / \mathrm{L}$ & $4.62 \pm 3.82$ & $5.39 \pm 3.75$ & $4.45 \pm 3.82$ & 0.117 \\
\hline nphocytes, $* 10^{\wedge} 9 / \mathrm{L}$ & $0.98 \pm 0.51$ & $0.85 \pm 0.45$ & $1.02 \pm 0.52$ & $0.041^{\mathrm{a}}$ \\
\hline \multicolumn{5}{|l|}{ lemical examination } \\
\hline $\mathrm{T}, \mathrm{U} / \mathrm{L}$ & $43 \pm 3$ & $52 \pm 9$ & $41 \pm 2$ & 0.085 \\
\hline $\mathrm{T}, \mathrm{U} / \mathrm{L}$ & $40 \pm 2$ & $48 \pm 9$ & $39 \pm 2$ & 0.135 \\
\hline $\mathrm{IL}, \mathrm{mmol} / \mathrm{L}$ & $10.9 \pm 6.8$ & $11.1 \pm 6.6$ & $10.9 \pm 6.8$ & 0.852 \\
\hline$\therefore \mu \mathrm{mol} / \mathrm{L}$ & $80.4 \pm 5.6$ & $74.2 \pm 3.4$ & $81.8 \pm 6.8$ & 0.609 \\
\hline $\mathrm{H}, \mathrm{U} / \mathrm{L}$ & $305 \pm 157$ & $377 \pm 130$ & $289 \pm 158$ & $<0.001^{\mathrm{b}}$ \\
\hline$\Gamma, \mathrm{pg} / \mathrm{ml}$ & $11 \pm 1$ & $13 \pm 2$ & $11 \pm 1$ & 0.498 \\
\hline -proBNP, pg/ml & $372 \pm 87$ & $437 \pm 92$ & $332 \pm 61$ & 0.096 \\
\hline \multicolumn{5}{|l|}{ nmatory factors } \\
\hline $1 \beta, \mathrm{pg} / \mathrm{ml}$ & $7.89 \pm 0.34$ & $6.27 \pm 0.50$ & $8.23 \pm 0.39$ & $0.028^{\mathrm{a}}$ \\
\hline $2 \mathrm{R}, \mathrm{U} / \mathrm{ml}$ & $796.30 \pm 25.1$ & $696.22 \pm 55.69$ & $817.57 \pm 28.44$ & 0.070 \\
\hline $6, \mathrm{pg} / \mathrm{ml}$ & $42.48 \pm 2.50$ & $40.37 \pm 7.55$ & $42.95 \pm 2.58$ & 0.684 \\
\hline $8, \mathrm{pg} / \mathrm{ml}$ & $44.10 \pm 1.85$ & $35.74 \pm 4.00$ & $45.88 \pm 2.06$ & $0.037^{a}$ \\
\hline $10, \mathrm{pg} / \mathrm{ml}$ & $7.69 \pm 0.14$ & $9.39 \pm 0.51$ & $6.18 \pm 0.16$ & $0.005^{b}$ \\
\hline $\mathrm{F}-\alpha, \mathrm{pg} / \mathrm{ml}$ & $10.54 \pm 0.92$ & $8.79 \pm 0.40$ & $10.91 \pm 0.21$ & $<0.001^{b}$ \\
\hline $\mathrm{T}, \mathrm{ng} / \mathrm{ml}$ & $0.28 \pm 0.09$ & $0.12 \pm 0.03$ & $0.32 \pm 0.11$ & 0.408 \\
\hline \multicolumn{5}{|l|}{ ulation function } \\
\hline $\mathrm{s}$ & $13 \pm 1$ & $14 \pm 1$ & $13 \pm 1$ & 0.148 \\
\hline $\mathrm{TT}, \mathrm{s}$ & $36 \pm 9$ & $37 \pm 8$ & $36 \pm 10$ & 0.528 \\
\hline Jimer, $\mu \mathrm{g} / \mathrm{ml}$ & $1.94 \pm 0.26$ & $3.33 \pm 0.89$ & $1.65 \pm 0.25$ & $0.015^{\mathrm{a}}$ \\
\hline \multicolumn{5}{|c|}{ : CT manifestations, number (\%) } \\
\hline ateral lesion & $113(57 \%)$ & $18(45 \%)$ & $95(59 \%)$ & 0.101 \\
\hline $\mathrm{O}$ & $115(58 \%)$ & $18(45 \%)$ & $97(61 \%)$ & 0.074 \\
\hline asolidation & $51(26 \%)$ & $12(30 \%)$ & $39(24 \%)$ & 0.465 \\
\hline
\end{tabular}

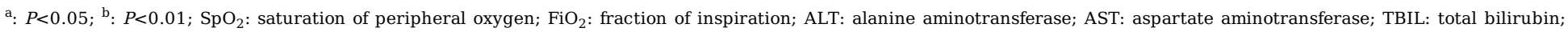

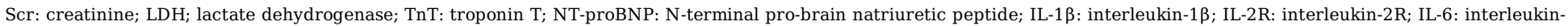

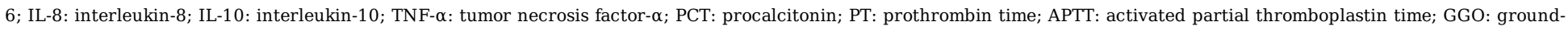
glass opacity

Table 3. Organ function, treatments and outcomes in the two groups during hospitalization

\begin{tabular}{|c|c|c|c|c|}
\hline & $\begin{array}{c}\text { All } \\
(n=200)\end{array}$ & $\begin{array}{c}\text { ACEI/ARB } \\
\text { group } \\
(n=40)\end{array}$ & $\begin{array}{l}\text { Control group } \\
(\mathrm{n}=160)\end{array}$ & $P$ \\
\hline \multicolumn{5}{|l|}{ n failure*, number (\%) } \\
\hline spiratory failure & $28(14 \%)$ & $8(20 \%)$ & $20(13 \%)$ & 0.221 \\
\hline Jck & $22(11 \%)$ & $9(23 \%)$ & $13(8 \%)$ & $<0.01^{b}$ \\
\hline I & $18(9 \%)$ & $4(10 \%)$ & $14(9 \%)$ & 0.805 \\
\hline agulation failure & $6(3 \%)$ & $1(3 \%)$ & $5(3 \%)$ & 0.836 \\
\hline er failure & $20(10 \%)$ & $5(13 \%)$ & $15(9 \%)$ & 0.556 \\
\hline \multicolumn{5}{|l|}{ ment, number (\%) } \\
\hline tibiotics & $141(71 \%)$ & $24(60 \%)$ & $117(73 \%)$ & 0.104 \\
\hline tiviral treatment & $188(94 \%)$ & $38(95 \%)$ & $150(94 \%)$ & 0.766 \\
\hline 1cocorticoids & $68(34 \%)$ & $10(25 \%)$ & $58(36 \%)$ & 0.179 \\
\hline ravenous immunoglobin & $47(24 \%)$ & $9(23 \%)$ & $38(24 \%)$ & 0.868 \\
\hline indard oxygen therapy & $169(85 \%)$ & $36(90 \%)$ & $133(83 \%)$ & 0.283 \\
\hline $\mathrm{NO}$ & $32(16 \%)$ & $7(18 \%)$ & $25(16 \%)$ & 0.772 \\
\hline PV & $17(9 \%)$ & $5(13 \%)$ & $12(8 \%)$ & 0.310 \\
\hline J & $17(9 \%)$ & $6(15 \%)$ & $11(7 \%)$ & 0.099 \\
\hline $\mathrm{MO}$ & $4(2 \%)$ & $1(3 \%)$ & $3(2 \%)$ & 0.801 \\
\hline soconstrictive agents & $17(9 \%)$ & $8(20 \%)$ & $9(6 \%)$ & $<0.01^{b}$ \\
\hline \multicolumn{5}{|l|}{ ome } \\
\hline hospital progression ${ }^{\#}$, number (\%) & $33(17 \%)$ & $6(15 \%)$ & $27(17 \%)$ & 0.775 \\
\hline hospital death, number (\%) & $21(11 \%)$ & $4(10 \%)$ & $17(11 \%)$ & 0.908 \\
\hline spital length of stay, days, mean $\pm \mathrm{SD}$ & $18 \pm 9$ & $23 \pm 12$ & $16 \pm 8$ & $<0.001^{\mathrm{b}}$ \\
\hline $\begin{array}{l}\text { ration of viral shedding, } \\
\text { Is, mean } \pm \mathrm{SD}\end{array}$ & $22 \pm 8$ & $25 \pm 7$ & $20 \pm 6$ & $0.031^{\mathrm{a}}$ \\
\hline e from nncet to death or dicrharre dave mean + Sn & $28+11$ & $33+14$ & $\begin{array}{c}27+10 \\
\text { Page } 9 / 11\end{array}$ & $<\cap \cap \cap 1^{b}$ \\
\hline
\end{tabular}




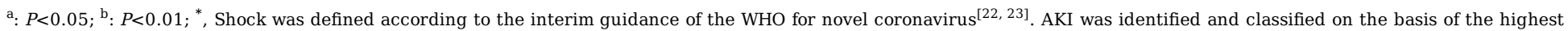

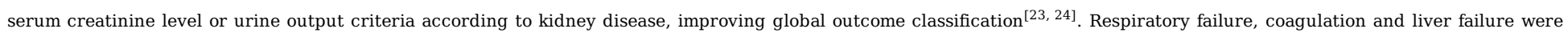

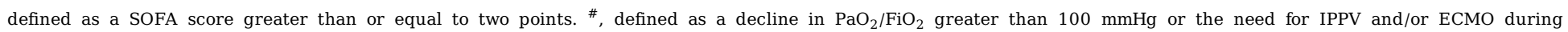

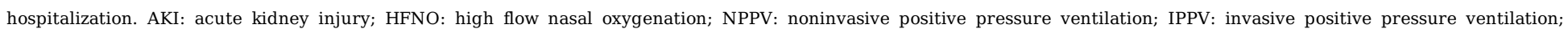
ECMO: extracorporeal membrane oxygenation

Table 4. The dynamic changes in the lymphocytes and inflammatory factors in patients continued and terminated ACEI/ARB during hospitalization

\begin{tabular}{|c|c|c|c|c|}
\hline & D1 & D7 & D14 & $P$ \\
\hline $\begin{array}{l}\text { tinued medication group, mean } \pm \mathrm{SD} \\
\text { ymphocytes, } * 10^{\wedge} 9 / \mathrm{L}\end{array}$ & $0.82 \pm 0.59$ & $1.33 \pm 0.36$ & $1.33 \pm 0.41$ & 0.265 \\
\hline$-1 \beta, \mathrm{pg} / \mathrm{mL}$ & $6.85 \pm 4.37$ & $6.35 \pm 2.84$ & $5.01 \pm 0.52$ & 0.153 \\
\hline$-10, \mathrm{pg} / \mathrm{mL}$ & $9.21 \pm 4.14$ & $14.69 \pm 9.41$ & $9.82 \pm 4.02$ & 0.095 \\
\hline $\mathrm{NF}-\alpha, \mathrm{pg} / \mathrm{mL}$ & $7.85 \pm 2.83$ & $8.17 \pm 2.45$ & $6.82 \pm 2.17$ & 0.639 \\
\hline \multicolumn{5}{|l|}{$\begin{array}{l}\text { minated medication group, } \\
\mathrm{n} \pm \mathrm{SD}\end{array}$} \\
\hline ymphocyte count, $* 10^{\wedge} 9 / \mathrm{L}$ & $1.09 \pm 0.52$ & $1.30 \pm 0.86$ & $1.60 \pm 0.52$ & $0.003^{b}$ \\
\hline$-1 \beta, \mathrm{pg} / \mathrm{mL}$ & $6.03 \pm 3.19$ & $10.78 \pm 6.88$ & $6.52 \pm 3.33$ & $0.002^{b}$ \\
\hline$-10, \mathrm{pg} / \mathrm{mL}$ & $8.08 \pm 3.40$ & $7.71 \pm 3.94$ & $5.53 \pm 1.52$ & 0.09 \\
\hline $\mathrm{NF}-\alpha, \mathrm{pg} / \mathrm{mL}$ & $9.19 \pm 2.86$ & $18.39 \pm 8.47$ & $6.15 \pm 2.15$ & $<0.001^{b}$ \\
\hline
\end{tabular}

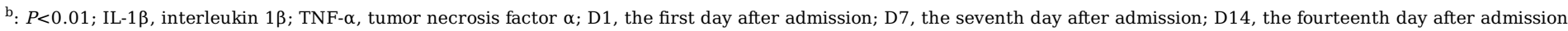

Table 5. Outcomes in patients who continued and those who terminated ACEIs/ARBs during hospitalization

\begin{tabular}{|c|c|c|c|}
\hline Outcomes & $\begin{array}{c}\text { Continued } \\
\text { ACEIs/ARBs } \\
(n=17)\end{array}$ & $\begin{array}{c}\text { Terminated } \\
\text { ACEIs/ARBs } \\
(n=34)\end{array}$ & $P$ \\
\hline In-hospital progression ${ }^{\#}$ & $2(12 \%)$ & $5(15 \%)$ & 0.774 \\
\hline In-hospital death & $0(0 \%)$ & $2(6 \%)$ & 0.308 \\
\hline Hospital length of stay, days & $27 \pm 9$ & $21 \pm 11$ & $0.037^{\mathrm{a}}$ \\
\hline Duration of viral shedding, days & $27 \pm 7$ & $21 \pm 7$ & $0.042^{\mathrm{a}}$ \\
\hline Time from onset to death or discharge, days & $33 \pm 13$ & $29 \pm 14$ & $0.038^{\mathrm{a}}$ \\
\hline
\end{tabular}

a: $P<0.05$; \#, defined as a decline in $\mathrm{PaO}_{2} / \mathrm{FiO}_{2}$ greater than $100 \mathrm{mmHg}$ or the need for IPPV and/or ECMO during hospitalization

\section{Figures}

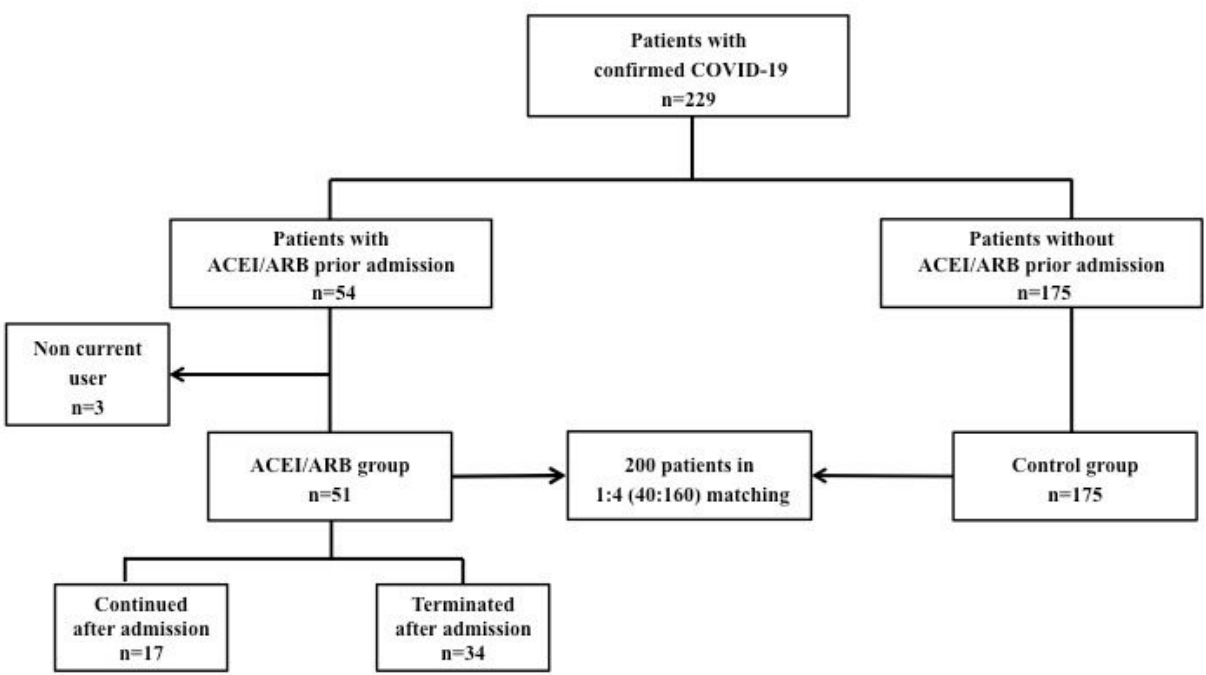

Figure 1

Flowchart. A flowchart illustrated the enrollment of patients in our study. From February 15, 2020 to March 25, 2020, a total of 217 patients with confirmed cases of COVID-19 were admitted, and 171 patients not taking an ACE inhibitor or ARB medication were designated as the control group. Among the 46 patients with a medication history, three of them were regarded as noncurrent users according to the definition, and 43 patients were ultimately divided into the ACEl/ARB group. Among the patients in the ACEI/ARB group, 15 continued medication during hospitalization, while the other 28 terminated medication. 
LY

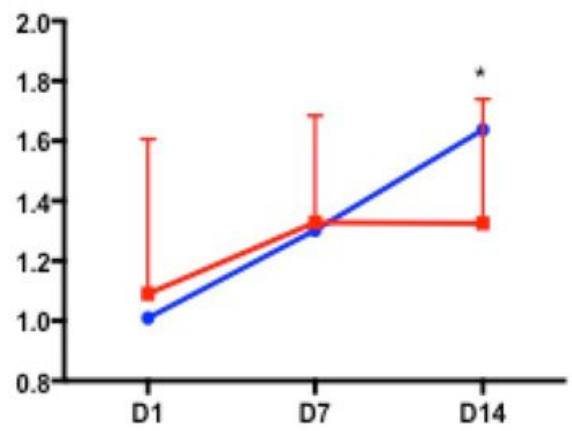

IL-1 $\beta$

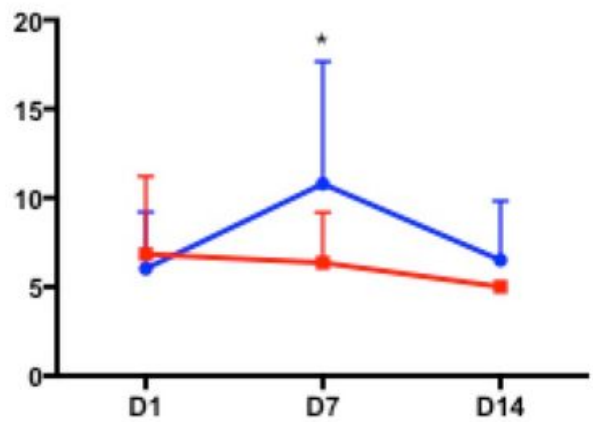

IL-10

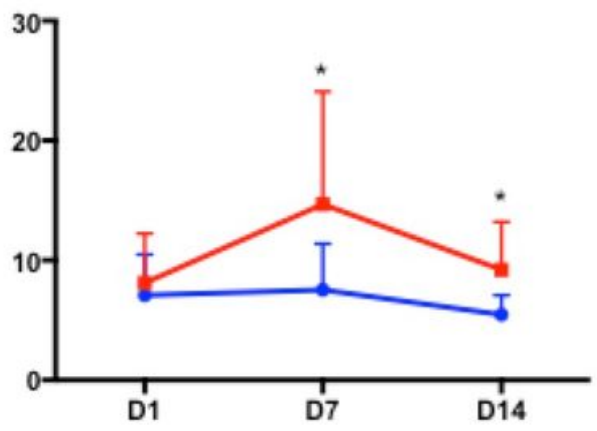

TNF- $\alpha$

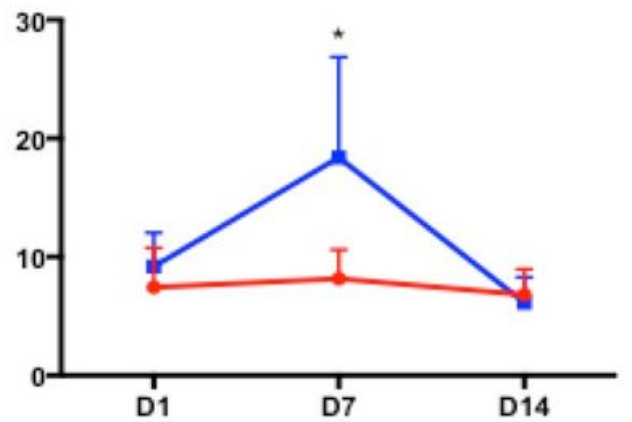

\section{Figure 2}

The dynamic changes in the lymphocyte counts and inflammatory factors between patients who continued and those who terminated ACEls/ARBs during hospitalization. Patients with continued use of ACE inhibitor or ARB had a consistently lower level of IL-1 $\beta$ and TNF-a at seventh day; while maintains higher level of the IL-10 from the seventh day to the fourteenth day than patients terminated the medication. The patients who terminated the medication had a trend of elevated lymphocyte counts from the first day to the fourteenth day, while they had a trend of higher levels of IL-1 $\beta$ and TNF- $a$ at the seventh day and returned to the baseline level on the fourteenth day. 